\title{
Adoption of BARI Recommended Potato (Solanum tuberosum) Varieties by the Potato Farmers of Bangladesh
}

\author{
M. I. Khali1 ${ }^{1}$, M. E. Haque ${ }^{2}$ and M. Z. Hoque ${ }^{2 *}$ \\ ${ }^{1}$ Bangladesh Agricultural Development Corporation (BADC); ${ }^{2}$ Department of Agricultural Extension \\ and Rural Development, Bangabandhu Sheikh Mujibur Rahman Agricultural University, Bangladesh \\ *Corresponding author and Email: zia.bsmrau@gmail.com
}

Received: 27 September 2012

Accepted: 06 December 2013

\begin{abstract}
This study was conducted to determine the extent of adoption of BARI recommended potato varieties by the potato growers in three Upazilas namely, Pirgachha of Rangpur, Munsiganj sadar of Munsiganj and Shibganj of Bogra district of Bangladesh. To achieve the objectives, the present research was designed to collect both qualitative and quantitative data. The study areas were selected purposively considering highly concentrated potato growing areas. Total numbers of potato growers in the selected areas were 581 from which 231 were selected as respondents following proportionate random sampling technique. A pre-tested interview schedule was used to collect data from the respondents during October, 2010 to February, 2011. The potato growers showed marked individual differences in their socio-economic characteristics and majority of them belonged to middle age category having small family size, primary level of education, small farm size, medium innovativeness and medium contact with extension personnel. The study revealed that the highest proportion $(68.4 \%)$ of the potato farmers belonged to high adoption category; whereas 6.5 percent fall in medium adoption category and 25.1 percent in low adoption category of BARI recommended potato varieties. Extent of adoption of BARI recommended potato varieties were found more or less equal in three different study areas, where the highest $(72.6 \%)$ portion of the potato farmers were in high adoption category in Munshiganj Sadar followed by 68.4 percent in Shibganj and 67.5 percent in Pirgachha. The studies also revealed that Diamant, Cardinal and Granola were the most popular varieties among all the released varieties of BARI and are largely grown in Munshiganj, Rangpur and Bogra, respectively. Farmers' education and knowledge about potato cultivation technology showed significant positive relationship with their adoption of BARI recommended potato varieties.
\end{abstract}

Keywords: Adoption, potato variety, BARI

\section{Introduction}

Potato (Solanum tuberosum) is the third largest food crop in Bangladesh and has recently occupied an important place in the list of major food and cash crops of Bangladesh (Ali and Haque, 2011). The area and production of potato in Bangladesh during 2009-2010 were 0.47 million hectares and 8.40 million MT, respectively. It is grown more or less in all the districts of Bangladesh But, better produced in the districts of Munsiganj, Bogra, Rangpur, Dinajpur and some parts of greater Comilla. The highest area concentration of potato was in Bogra (48700 hectares) in 2008-2009. This was followed by Rangpur (41200 hectares), Dinaipur 
(36955 hectares) and Munshiganj (32850 hectares) during the same year (BBS, 2009). Per hectare yield of potato remained static at around 12.92 MT up to 2000-2001. However, the increased yields of 17.80 MT per hectare during 2009-2010 were mainly due to use of quality seeds of modern varieties and appropriate production technologies (DAE, 2010).

There are about 27 local varieties of potatoes cultivated in different parts of the country. They have familiar local names. It is estimated that local varieties were cultivated in about $1,13,540$ acres of land, producing 3,09,800 $\mathrm{m}$ tons of tubers during 1997-98. Some of the popular local varieties are: (a) Sheel Bilatee- mostly cultivated in Rangpur. The tuber is oblong, reddish. Each tuber weighs about $30 \mathrm{~g}$; (b) Lal Sheel-primarily cultivated in Bogra with round tubers reddish in color and each having a weight of about $55 \mathrm{~g}$. This variety is also known as Lal Madda and Bograi; (c) Lal Pakri - cultivated widely in Dinajpur, Bogra and Sirajganj districts with reddish and round tubers, each weighing about 30 g; (d) Du Hajari - mostly cultivated in Chittagong area. Tubers appear round and pale, each weighing about $25 \mathrm{~g}$. Among other indigenous varieties Jhau Bilatee and Suryamukhi are notable. In the last few decades, several dozens of high yielding varieties (HYV) of potato were brought to Bangladesh and tried experimentally under local conditions before they were recommended for general cultivation. During the 1970s, about 16 varieties were initially selected, but subsequently 10 were dropped. Through constant evaluation of the traits, varietal performance, and considerations of other characteristics, about $10 \mathrm{HYV}$ have been released for cultivation in the country. However, huge amount of potato seeds are imported every year by the Bangladesh Agricultural Development Corporation (BADC) for distribution among farmers.

Bangladesh Agricultural Research Institute (BARI) has also established a farm at Debiganj in Panchagar district for production of HYV seed potatoes. Among the high yielding popular varieties, some notable varieties are: (a) Cardinal- probably most popular among the foreign varieties with oblong and reddish tubers, shallow eyes, and smooth skin. The variety has been introduced from Holland and has yield potential of 20-25 m tons per ha; (b) Diamant another Holland- variety with oval to oblong shape, pale yellow tubers, smooth skin, and shallow eyes. It is quite disease resistant. Per hectare yield ranges from 18-24 m tons; (c) Kufri Shindhury - tubers are reddish and round, and eyes are deep with rough skin. This variety was introduced from India and is comparatively less susceptible to pests and diseases. It has a yield potential of 18 to $22 \mathrm{~m}$ tons per ha. Other notable exotic varieties are Patronis, Alpha, Archa, Multa, Ukama, Hira, Maurin, Origo, Alisa, etc. In recent years, the Tuber Crops Research Centre of BARI has collected many new varieties of potato from the International Potato Research Centre, Peru and from other sources. These are being tested under Bangladesh field conditions to determine whether they can be recommended for commercial cultivation in the country. The Centre has already made good contribution towards the development of some high yielding potato varieties (Anonymous, 2006).

Usually, farmers follow a different level of production technologies depending upon their infrastructural facilities and socio- economic conditions which ultimately result variability in yields of potato (Elias et al., 1992). The proper management is fully dependent upon ability of the manager, his attitude, knowledge, skill and resource (Hussain and Islam, 1986). Farmers' production performance depends on physical resources and technology available to them as well as existing farm management conditions. Efficient use of inputs and technologies can help farmers to get higher production from a given amount of resources. Several studies in other countries have shown that there is a significant potential for raising agricultural output or profitability by improving productive efficiency using existing resources (Rahman, 2002). There are many studies reported on potato cultivation and its profitability, but very little research has 
been found regarding adoption of BARI recommended potato varieties. Moreover, scientists do not know the actual performance of the released potato varieties and extension personnel do not know the extent of adoption of recommended potato varieties. So, it is needless to say that research is necessary to have a clear idea about the adoption of BARI recommended potato varieties. In view of the above discussion, this study attempted to achieve the following specific objectives:

(i) To describe the selected socio-economic characteristics of the potato growers;

(ii) To determine the extent of adoption of BARI recommended potato varieties by the potato farmers in the selected study area;

(iii) To compare the extent of adoption of BARI recommended potato varieties among the farmers of selected potato growing areas;

(iv) To identify the most suitable BARI recommended potato varieties in the study areas; and

(v) To find out the relationships between socio-economic characteristics of the potato farmers and their adoption of BARI recommended potato varieties.

\section{Methodology}

The present study was a descriptive and diagnostic type of research. The study was conducted in three Upazilas namely, pirgachha of Rangpur district, Munsiganj sadar of Munsiganj district and Shibganj of Bogra district of Bangladesh. The study areas were selected purposively in consideration of highly concentrated potato growing areas. Total number of potato growers in the selected areas was 581, from which 231 were selected as respondents following proportionate random sampling technique. A pre-tested interview schedule was used to collect data from the respondents during October, 2010 to February, 2011. The independent variables of the study were the selected socio-economic characteristics of the potato farmers which included: age, years of schooling, family size, farm size, annual income, farming experience, Organizational participation, extension contact, participation in training program, innovativeness, attitude toward improved potato production technologies and knowledge on improved potato cultivation technologies. Extent of adoption of BARI recommended potato varieties was considered as the dependent variable of this study. The independent variable was measured following a standard procedure. Tuber Crop Research Centre of Bangladesh Agricultural Research Institute (BARI) recommended the potato varieties Diamant, Cardinal, Multa, Asterix, Dheera, Espirit, Felsina, Granola, Heera, Patrones, Binella, Elvira, Ultra, Kufri Sinduri and BARI TPS-Alu which were considered as improved variety of potato.

Extent of Adoption of improved potato cultivation technologies was calculated using the formula given by Kashem (2004) as:

Extent of adoption of BARI recommended potato varieties $=$

Area covered by recommended potato varieties X 100

Potential area for potato cultivation

After collection of data, all the information contained in the interview were edited, checked and cross checked, compiled and coded for analysis and interpretation using SPSS program. Qualitative data were converted into quantitative form by means of suitable scoring techniques. All personal traits were categorized and arranged in simple tables for description. For presentation of data, various statistical measures such as number, range, mean, percentage and standard deviation were used to describe selected characteristics of the potato farmers. Coefficients of correlation ( $r$ ) were computed to find out the relationship between socio-economic profile of the respondents and their adoption of BARI recommended potato varieties.

\section{Results and Discussion}

\subsection{Socioeconomic characteristics of the potato growers}


Table 1 describes the socio-economic characteristics of potato farmers are age, years of schooling, family size, farm size, annual income, farming experience, Organizational participation, extension contact, participation in training program, innovativeness, attitude toward improved potato production technologies and knowledge on improved potato cultivation technologies.

Data presented in Table 1 reveals that the highest proportion of the respondents was identified as middle aged $(50.60 \%)$, having secondary level of education $(34.20 \%)$, small family size $(47.20 \%)$, small farm size $(67.50 \%)$, low farming experience $(48.90 \%)$, medium income $(84.80 \%)$, low organizational participation $(51 \%)$, medium extension contact $(63.20 \%)$, poor training experience $(52.40 \%)$, medium innovativeness $(55.40 \%)$, moderately favorable attitude $(71.10 \%)$, and medium level of knowledge $(60.6 \%)$ on improved potato cultivation technologies.

\subsection{Adoption scale of BARI recommended potato varieties}

Potato varieties released by BARI in different times were considered as HYV of potato. The adoption scale of BARI recommended varieties ranged from 50 to 100 , the average being 86.52 with standard deviation of 19.80 . Based on the adoption score the respondents were classified in to three categories (Table 2). Data presented in Table 2 indicates that the highest proportion (68.4\%) of the potato farmers belonged to high adoption category whereas 6.5 percent fall in medium adoption categories and 25.1 percent under low adoption category. Comparative adoption of BARI recommended potato variety in different study areas are described in Figure 1.

As shown in Figure 1, the highest (72.6\%) portion of the potato farmers were high adoption category in Munshiganj Sadar followed by 68.4 percent in Shibganj and 67.5 percent in Pirgachha, whereas 9.5 percent of them in Pirgachha were medium adoption category followed by 5.5 percent in Shibganj. Extent of adoption of BARI recommended potato varieties were found to be more or less equal in three different study areas. Among the BARI recommended potato varieties, 6 varieties namely Diamond, Cardinal, Binella, Granola, Heera and BARI TPS- 1 were cultivated by the farmers of the selected study locations.

Information revealed in Figure 2 indicates that most of the potato farmers $(82 \%)$ in Munshiganj Sadar used Diamant variety followed by 8 percent used Cardinal, 7 percent used Granola and 3 precent used Binella. In case of Pirgachha, highest $(45 \%)$ of the potato farmers used Cardinal followed by 23 percent used Diamant, 22 percent Granola, 7 percent used other varieties and only 2.74 percent used BARI TPS 1 variety. In case of Shibganj, 53 percent potato farmers used Granola followed by 32 percent used Diamant, 12 percent used Cardinal, 4 percent used BARI TPS variety and only 3 percent used other varieties. It is evinced from the figure that Diamant, Cardinal and Granola were the most popular varieties among all the released varieties of BARI.

\subsection{Relationship between socio-economic characteristics of the respondents and adoption of BARI recommended potato variety}

Education of the respondents had significant positive relationship with the adoption of BARI recommended potato varieties indicating that more education of the respondents leads to a tendency towards more adoption. Similar relationship was also obtained by Hoque et al., (2010), Omoregbee and Okoedo-Okojie, 2008; Saka et al., 2005; Salasya et al., 2007; Amin and Islam, 2009, Akter (2007), Aurangozeb (2002), and Sardar (2002). Knowledge of the farmers on improved potato production technologies also showed significant positive relationship with adoption of BARI recommended potato varieties. Age, family size, farm size, annual income, farming experience, training experience, attitude towards potato cultivation and innovativeness did not have any significant relationship in the adoption at 0.05 level of probability. 
Table 1. Distribution of the respondents according to their socio-economic characteristics

\begin{tabular}{|c|c|c|c|c|c|}
\hline Character & Unit & Categories & $\%$ & Mean & SD \\
\hline $\begin{array}{l}\text { Age of the } \\
\text { respondent }\end{array}$ & Actual year & $\begin{array}{l}\text { Young aged ( } 24 \text { to } 35) \\
\text { Middle aged (36-50) } \\
\text { Old }(>50)\end{array}$ & $\begin{array}{l}34.2 \\
50.6 \\
15.2\end{array}$ & 41.11 & 9.60 \\
\hline $\begin{array}{l}\text { Years of Schooling } \\
\text { of the respondent }\end{array}$ & $\begin{array}{l}\text { Year of } \\
\text { schooling }\end{array}$ & $\begin{array}{l}\text { No education }(0) \\
\text { Primary (1-5) } \\
\text { Secondary (6-10) } \\
\text { Higher secondary (11 to } 12) \\
\text { Above higher secondary }(>12)\end{array}$ & $\begin{array}{c}32 \\
29.9 \\
34.2 \\
2.6 \\
1.3 \\
\end{array}$ & 4.44 & 3.69 \\
\hline Family size & Number & $\begin{array}{l}\text { Small (up to } 4) \\
\text { Medium ( } 5 \text { to } 6) \\
\text { Large ( } 7 \text { and above) }\end{array}$ & $\begin{array}{l}47.2 \\
41.6 \\
11.3 \\
\end{array}$ & 4.82 & 1.42 \\
\hline Farm size & $\begin{array}{l}\text { Actual } \\
\text { (ha) }\end{array}$ & $\begin{array}{l}\text { Small }(>0.03 \text { to } 1) \\
\text { Medium ( }>1 \text { to } 3) \\
\text { Large (above } 3)\end{array}$ & $\begin{array}{l}11.3 \\
56.3 \\
26.8 \\
\end{array}$ & 0.99 & 0.88 \\
\hline Farming experience & $\begin{array}{l}\text { Actual } \\
\text { (year) }\end{array}$ & $\begin{array}{l}\text { Low (Up to } 10) \\
\text { Medium (11-20) } \\
\text { High (above } 20) \\
\end{array}$ & $\begin{array}{c}48.9 \\
42.9 \\
8.2 \\
\end{array}$ & 11.40 & 5.21 \\
\hline $\begin{array}{l}\text { Annual family } \\
\text { income }\end{array}$ & Taka & $\begin{array}{l}\text { Low (75248 to } 90000 \mathrm{Tk}) \\
\text { Medium (90001-315000 Tk) } \\
\text { High (above } 315000 \mathrm{Tk})\end{array}$ & $\begin{array}{c}2.6 \\
84.5 \\
12.6 \\
\end{array}$ & 202822 & 112732 \\
\hline $\begin{array}{l}\text { Organizational } \\
\text { participation }\end{array}$ & Score & $\begin{array}{l}\text { No participation }(0) \\
\text { Low participation (1-5) } \\
\text { Medium participation (6-10) } \\
\text { High participation (above } 10)\end{array}$ & $\begin{array}{l}7.8 \\
51 \\
35 \\
1.2 \\
\end{array}$ & 4.67 & 3.23 \\
\hline Extension contact & Score & $\begin{array}{l}\text { Low (up to 13) } \\
\text { Medium (14 to 25) } \\
\text { High (above 25) }\end{array}$ & $\begin{array}{l}18.2 \\
63.2 \\
18.6\end{array}$ & 19.33 & 6.28 \\
\hline $\begin{array}{l}\text { Participation in } \\
\text { training programme }\end{array}$ & Score & $\begin{array}{l}\text { No training }(0) \\
\text { Short training }(1-3) \\
\text { Medium training ( } 4 \& \text { above) }\end{array}$ & $\begin{array}{c}43.7 \\
52.4 \\
3.9\end{array}$ & 1.28 & 1.35 \\
\hline Innovativeness & $\begin{array}{l}\text { No. of year } \\
\text { used }\end{array}$ & $\begin{array}{l}\text { Low innovativeness (1-16) } \\
\text { Medium innovativeness (17-32) } \\
\text { High innovativeness (Above } \\
\text { 32) }\end{array}$ & $\begin{array}{l}10.8 \\
55.4 \\
33.8\end{array}$ & 28.54 & 6.91 \\
\hline $\begin{array}{l}\text { Attitude towards } \\
\text { improved potato } \\
\text { production }\end{array}$ & Score & $\begin{array}{l}\text { Unfavorable (Up to 70) } \\
\text { Moderately favorable (71-101) } \\
\text { Highly Favorable (102 and } \\
\text { Above) }\end{array}$ & $\begin{array}{l}17.7 \\
71.4 \\
10.8\end{array}$ & 86.16 & 15.42 \\
\hline $\begin{array}{l}\text { Knowledge on } \\
\text { potato cultivation } \\
\text { technologies }\end{array}$ & Score & $\begin{array}{l}\text { Low (Up to } 8) \\
\text { Medium (9-14) } \\
\text { High (15 and above) }\end{array}$ & $\begin{array}{l}23.8 \\
60.6 \\
15.6\end{array}$ & 11.39 & 3.07 \\
\hline
\end{tabular}


Table 2. Distribution of the potato farmers according to their adoption of BARI recommended varieties

\begin{tabular}{lcccc}
\hline Category & \multicolumn{2}{c}{ Potato farmers } & Mean & SD \\
\cline { 2 - 3 } & Number & Percent & & \\
\hline Low extent of adoption (50 to 66) & 58 & 25.1 & \\
Medium extent of adoption (67 to 83) & 15 & 6.5 & 86.52 & 19.80 \\
High extent of adoption (84 to 100) & 158 & 68.4 & & \\
Total & 231 & 100 & \\
\hline
\end{tabular}



Fig. 1. Comparative adoption of BARI recommended potato varieties in different study areas

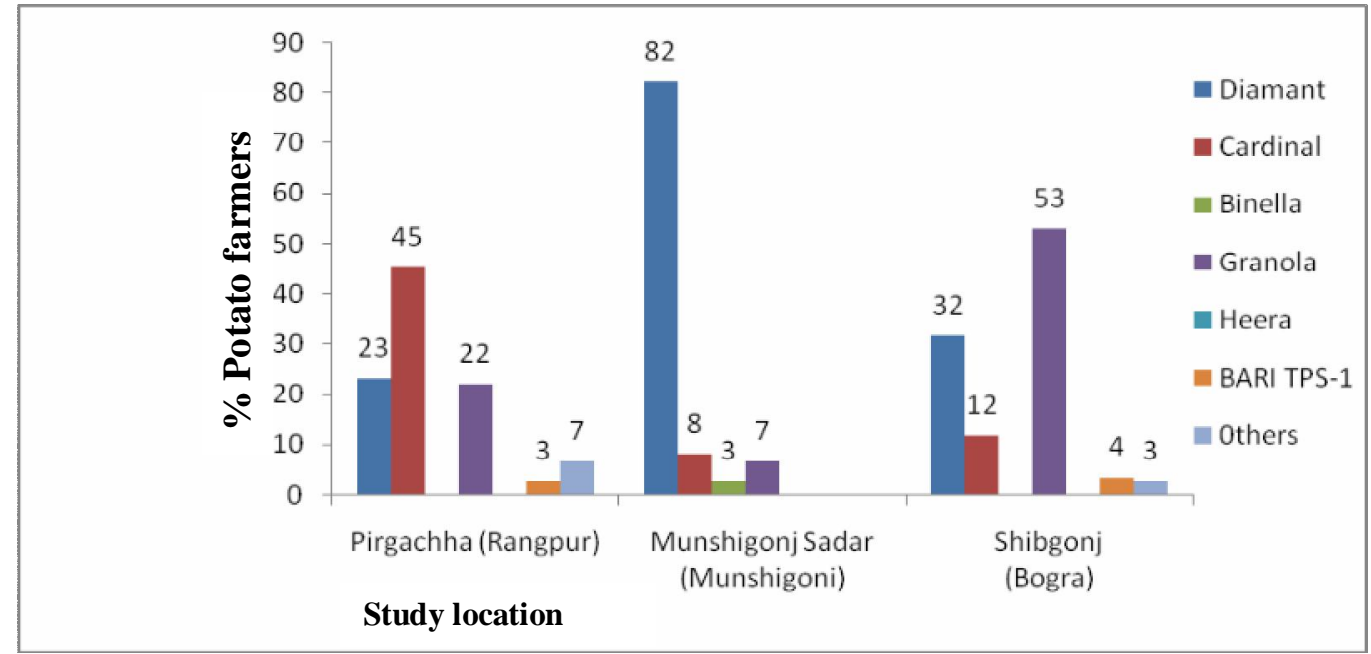

Fig. 2. Distribution of the respondents according to their adoption of BARI recommended variety 
Table 3. Correlation coefficient between socio-economic characteristics of the respondents and their adoption of BARI recommended potato variety

\begin{tabular}{lcc}
\hline Independent variable & Dependent variable & Coefficient of correlation ('r') \\
\hline Age of farmer & \\
Farmers education & & 0.017 \\
Family size & & $0.231(* *)$ \\
Farm size & & 0.026 \\
Annual income & Adoption of BARI & 0.012 \\
Farming experience & Recommended potato variety & 0.043 \\
Organizational participation & & 0.079 \\
Extension contact & & 0.082 \\
Training experience & & 0.037 \\
Innovativeness & & 0.053 \\
Attitude & & 0.006 \\
Knowledge & 0.065 \\
\hline
\end{tabular}

*Correlation is significant at the 0.05 level (2-tailed)

** Correlation is significant at the 0.01 level (2-tailed)

\section{Conclusions and Recommendation}

The highest proportion $(68.4 \%)$ of the potato farmers belonged to high adoption category, whereas only 6.5 percent fall in medium adoption categories and 25.1 percent were under low adoption category. So, there remains further scope to increase the level of adoption of recommended potato varieties. For this, there is a need for strengthening extension services provided by GOs and NGOs to ensure a continuous flow of information and technical know-how to the potato growers for enhancing their skills and knowledge in the respective areas. Adoption of recommended potato varieties by the potato farmers was increased with higher level of education and knowledge. It implies that, the socio-economic characteristics of the potato growers have profound influence on their adoption of recommended potato varieties. Therefore, government (specially DAE, BADC) and non- government (BRAC) development initiatives should consider these attributes while formulating any capacity strengthening programs and projects related to potato cultivation.

\section{References}

Akter, L. 2007. Adoption of Improved Tomato Varieties by the Farmers in a Selected Area of Bangladesh. MS Thesis, Dept. of Agricultural Extension Education, Bangladesh Agricultural University, Mymensingh.

Ali, M. S. and Haque, A. 2011. Potato for food Security in SAARC Countries; SAARC Seed Congress and Fair 2011, Dhaka, Bangladesh.

Amin, M. R. and Islam, M. R. 2009. Adoption of recommended Potato Cultivation Practices by the Farmers in Some Selected Areas of Naogaon District. Bangladesh Journal of Extension Education, 21(1\&2): 125-132.

Anonymous.2006.http://www.banglapedia.org/H T/P_0236.HTM

Aurangozeb, M. K. 2002. Adoption of Integrated Homestead Farming Technologies by the Rural Women in RDRS. MS Thesis, Dept. of Agricultural Extension Education, Bangladesh Agricultural University, Mymensingh. 
BBS (Bangladesh Bureau of Statistics). 2009. Yearbook of Agricultural Statistics in Bangladesh, Bangladesh Bureau of Statistics, Ministry of Planning, Government of the People's Republic of Bangladesh, Dhaka.

DAE (Department of Agricultural Extension). 2010. Agricultural Extension Manual, Khamarbari, Farmgate, Dhaka.

Elias, S. M., Miah, M. R. U., Hossain, M. J., Torofder, G. S. and Islam, M. S. 1992. Effect of potassium on the growth and yield of potato. Bangladesh Journal of Agricultural Research, 17 (7): 91-93.

Hoque, M. Z., Haque, M. E., Afrad, M. S. I. and Hossain, M. A. 2010. Adoption of Farming Technology by the Charland Farmers. Bangladesh Journal of Extension Education, 22 (1\&2):49-55.

Hussain, M. S. and Islam, S. M. F. 1986. Farm Level Price Behavior of Major Agricultural Products in Bangladesh. Bangladesh Journal of Agricultural Economics, 14(2): 88-96.

Kashem, M. A. 2004. Measurement of Adoption. In: Fundamentals of Extension Education. Bangladesh Agricultural University, Mymensingh. 64-67 pp.
Omoregbee, F. and Okoedo-Okojie, D. U. 2008. Farmers' characteristics and adoption of recommended practices under the Fadama Project Scheme in Edo State, Nigeria. Global Journal of Agricultural Sciences, 7(1): 45-48.

Rahman, S. M. M. 2002. Seed Uptake Programme of RDRS: It's Impact on Livelihood Asset Building of Resource Poor Farmers. MS Thesis, Dept. of Agricultural Extension Education, Bangladesh Agricultural University, Mymensingh.

Saka, J. O., Okoruwa, V. O., Lawal, B. O. and Ajijola, S. 2005. Adoption of Improved Rice varieties among Small-Holder Farmers in South-Western Nigeria. World Journal of Agricultural Sciences, 1 (1): 42-49.

Salasya, B., Mwangi, W., Mwabu, D. and Diallo, A. 2007. Factors influencing adoption of stress-tolerant maize hybrid (WH 502) in Western Kenya. African Journal of Agricultural Research, 2(10): 544-551.

Sardar, M. H. U. 2002. Adoption of IPM Practices by the Farmers under PETRA MS Thesis, Dept. of Agricultural Extension Education, Bangladesh Agricultural University, Mymensingh. 